\title{
PERBANDINGAN TINGKAT BAGI HASIL SIMPANAN MUDHARABAH DAN MODAL SENDIRI ANTAR BANK UMUM SYARIAH DI INDONESIA PERIODE 2012-201511
}

\author{
Andre Kurniawan \\ Mahasiswa Program Studi S1 Ekonomi Islam Fakultas Ekonomi dan Bisnis Universitas Airlangga \\ Email: andre.kurniawan-12@feb.unair.ac.id
}

Achsania Hendratmi

Departemen Ekonomi Syariah Fakultas Ekonomi dan Bisnis Universitas Airlangga

Email: achsania.hendratmi@feb.unair.ac.id

\begin{abstract}
:
This study aims to know the return level which is given to capital stockholders and also customers or clients that use 'aqd mudharabah between islamic banks. Return represents that a bank can manage its fund well by giving satisfying return to capital stockholders and customers or depositors. This research compares ROE and ROMD inter-islamic banks. This research uses quantitativ-comparative method and it uses six islamic banks, and then, the researcher did different test of ROE and ROMD to it. Different test of ROE uses Kruskal-Wallis and Mann-Whitney tests, while different test of ROMD uses ANOVA and LSD tests. The result of ROE different test shows that there is a significant difference between one islamic bank to the others in Indonesia. The result of ROMD different test shows that there is no a significant difference between one islamic bank to the others in Indonesia.
\end{abstract}

Keywords: Return, Mudharabah, Capital, Islamic Bank.

\section{PENDAHULUAN}

\section{Latar Belakang}

Perkembangan perbankan syariah di Indonesia diawali dengan berdirinya PT Bank Muamalat Indonesia (BMI) yang didirikan pada 1 November 1991 dan mulai beroperasi pada 1 Mei 1992. Pemerintah Indonesia sangat mendukung hadirnya perbankan syariah hal ini ditunjukkan dengan terbitnya UndangUndang No. 7 tahun 1992 dan PP No. 72 tahun 1992 yang menguatkan dasar hukum kegiatan operasional bank syariah di Indonesia. Secara perlahan, bank syariah mampu memenuhi kebutuhan masyarakat yang menginginkan sistem perbankan yang berlandaskan pada syariat Islam. Namun demikian, perbankan syariah belum memiliki landasan hukum yang kuat. Oleh karena itu, diperlukan UU 1) Jurnal ini merupakan bagian dari skripsi dari Andre Kurniawan, NIM : 041211433087 yang diuji pada 8 Februari 2017

Perbankan Syariah tersendiri untuk mempercepat pertumbuhan dan perkembangan bank syariah. Maka muncul UU No.21 Tahun 2008 mengenai Perbankan Syariah. Di dalam UU tersebut perbankan syariah dimungkinkan untuk memperluas kegiatan usaha atau menerbitkan produk.

Pengumpulan dana yang dilakukan oleh bank syariah termasuk investasi bagi masyarakat yang ingin menaruh dananya di bank syariah. Dengan banyaknya bank syariah sekarang ini orang muslim tidak kebingungan apabila ingin menginvestasikan dananya. Investasi adalah komitmen atas sejumlah dana atau sumber daya lain yang dilakukan pada saat ini dengan tujuan memperoleh keuntungan di masa datang (Tandelilin, 
Kurniawan, et al/Jurnal Ekonomi Syariah Teori dan Terapan Vol. 4 No. 10 Oktober 2017: 847-859; ANALISIS PERBANDINGAN RETURN MODAL SENDIRI DAN EQUIVALENT RATE SIMPANAN MUDHARABAH PADA BANK UMUM SYARIAH DI INDONESIA PERIODE 2012-2015

2001:4). Investasi yang Islami adalah pengorbanan sumber daya pada masa sekarang untuk mendapatkan hasil yang pasti, dengan harapan memperoleh hasil yang lebih besar di masa yang akan datang, baik langsung maupun tidak langsung, seraya tetap berpijak pada prinsip-prinsip syariah secara menyeluruh (kaffah) (Nafik, 2009:70).

Dana yang diinvestasikan dalam bentuk saham berfungsi sebagai penyangga dan penyerap kegagalan atau kerugian bank dan melindungi kepentingan para pemegang rekening titipan (wadiah) atau pinjaman (qard), terutama atas aktiva yang didanai oleh modal sendiri dan dana-dana wadiah atau qard (Arifin, 2003:152). Dana yang berasal dari pemegang saham (shareholders fund) merupakan dana yang dapat ditingkatkan bank melalui penjualan saham umum (common shares) kepada publik. Apabila saham yang terdapat dalam portepel belum habis terjual, sedangkan kebutuhan dana masih perlu, pencariannya dapat dilakukan dengan menjual saham kepada pemegang saham lama. Akan tetapi, jika tujuan perusahaan untuk melakukan ekspansi, maka perusahaan dapat mengeluarkan saham baru di pasar modal ( Kasmir, 2010:47).

Dana yang diinvestasikan dalam bentuk saham berfungsi sebagai penyangga dan penyerap kegagalan atau kerugian bank dan melindungi kepentingan para pemegang rekening titipan (wadiah) atau pinjaman (qard), terutama atas aktiva yang didanai oleh modal sendiri dan dana-dana wadiah atau qard (Arifin, 2003:152). Dana yang berasal dari pemegang saham (shareholders fund) merupakan dana yang dapat ditingkatkan bank melalui penjualan saham umum (common shares) kepada publik. Apabila saham yang terdapat dalam portepel belum habis terjual, sedangkan kebutuhan dana masih perlu, pencariannya dapat dilakukan dengan menjual saham kepada pemegang saham lama. Akan tetapi, jika tujuan perusahaan untuk melakukan ekspansi, maka perusahaan dapat mengeluarkan saham baru di pasar modal ( Kasmir, 2010:47).

Dana yang ditanamkan oleh para pemegang saham atau modal saham memiliki banyak risiko yang dapat mengikis nilai dana itu sendiri. Para pemegang saham memiliki risiko kehilangan dananya apabila perusahaan perbankan tidak berjalan dengan baik. Sebaliknya dana ini juga dapat meningkatkan nilainya apabila perbankan berjalan dengan baik (Rosly dan Zaini, 2008). Selain investasi dalam bentuk modal saham, nasabah yang ingin menginvestasikan dananya pada bank Syariah bisa menaruh dananya dalam akad mudharabah.

Investasi berbasis bagi hasil yang paling popular dalam transaksi bank Syariah adalah akad bagi hasil mudharabah. Khususnya dalam sisi dana 
Kurniawan, et al/Jurnal Ekonomi Syariah Teori dan Terapan Vol. 4 No. 10 Oktober 2017: 847-859; ANALISIS PERBANDINGAN RETURN MODAL SENDIRI DAN EQUIVALENT RATE SIMPANAN MUDHARABAH PADA BANK UMUM SYARIAH DI INDONESIA PERIODE 2012-2015

deposito, bank syariah menggunakan akad mudharbah sesuai dengan fatwa MUI No:03/DSN-MUI/IV/2000. Penggunaan akad mudharabah tersebut yang membedakan antara deposito bank syariah dengan deposito bank konvensional yang menggunakan prinsip bunga. Akad mudharabah yang digunakan dalam produk bank syariah selain deposito ialah tabungan mudharabah.

Mudharabah merupakan konsep yang didukung oleh syariat Islam dimana salah satu pihak menyediakan modal (shahibul maal) sementara pihak yang lain bertindak sebagai pelaksana usaha (mudharib). Mudharabah dalam bank syariah meliputi investasi tidak terikat (unrestricted investment account) dan investasi terikat (restricted investment account), perbedaan keduanya terletak pada kemauan pemilik dana dalam memberikan hak dan ototritas terhadap mudharib (Antonio, 2001:138).

Laba yang diperoleh dari akad mudharabah berasal dari bisnis yang dimiliki oleh kedua belah pihak berdasarkan rasio keuntungan yang telah disepakati. Kerugian ditanggung oleh shahibul maal apabila kerugian bukan disebabkan oleh kelalaian mudharib. Bank syariah menggunakan konsep two tier mudharabah, yaitu bank syariah berfungsi dan berperan sebagai mudharib bagi nasabah bank sedangkan dalam pembiayaan bank syari'ah bertindak sebagai pemilik dana atau shahibul maal.
Selain itu, bank syari'ah juga dapat bertindak sebagai agen investasi yang mempertemukan pemilik dana dan pengusaha (Diao dan Mbow: 2011). Bagi hasil akan dibagi pada ketiga pihak tersebut menurut rasio yang telah disepakati pada saat akad dan kerugian ditanggung sebesar modal yang disertakan. Sistem bagi hasil yang diterapkan di dalam perbankan syariah terdiri dari dua sistem, yaitu : profit sharing dan revenue sharing. Didasarkan penjelasan mengenai investasi yang dilakukan pada perbankan syariah dalam bentuk modal saham dan juga akad bagi hasil mudharabah. Peneliti untuk lebih lanjut membahas mengenai ROE dan ROMD di bank umum Syariah. Dari keterangan tersebut, peneliti mengambil judul "Analisis Perbandingan return modal saham dan akad mudharabah pada Bank Umum Syariah di Indonesia periode 2013-2015"

\section{LANDASAN TEORI}

Menurut Halim (2005:4) investasi pada hakikatnya merupakan penempatan sejumlah dana dengan harapan memperoleh keuntungan di masa mendatang. Dalam aktivitasnya, menurut Willian F.Sharpe (2005:1) dalam Fahmi (2006:3) investasi pada umumnya dikenal dalam dua bentuk yaitu, pertama investasi nyata (real investment) secara umum melibatkan asset berwujud seperti tanah, mesin-mesin, atau pabrik. Kedua jenis investasi keuangan (financial investment) melibatkan kontrak tertulis, 
Kurniawan, et al/Jurnal Ekonomi Syariah Teori dan Terapan Vol. 4 No. 10 Oktober 2017: 847-859; ANALISIS PERBANDINGAN RETURN MODAL SENDIRI DAN EQUIVALENT RATE SIMPANAN MUDHARABAH PADA BANK UMUM SYARIAH DI INDONESIA PERIODE 2012-2015

seperti saham biasa dan obligasi. Perekonomian modern lebih condong kepada investasi keuangan. Sehingga kita bisa melihat salah satu ukuran ekonomi suatu Negara tersebut maju, adalah keberadaan dan kualitas dari bursa efeknya oleh para pebisnis.

Dalam perspektif Islam, investasi adalah kegiatan yang sangat dianjurkan karena dapat mendorong pertumbuhan ekonomi yang ditandai dengan meningkatnya transaksi jual-beli, simpanpinjam, sewa-menyewa, gadai, dan kegiatan ekonomi lainnya (Suryomurti, 2011 :3). Menurut Nurul Huda, dkk (2007:18) konsep investasi selain sebagai pengetahuan juga bernuansa spiritual karena menggunakan norma syariah, sekaligus merupakan hakikat dari sebuah ilmu dan amal, oleh karenanya investasi sangat dianjurkan bagi setiap muslim.

Modal sendiri adalah modal yang berasal dari pemilik perusahaan dan yang tertanam di dalam perusahaan untuk jangka waktu yang tidak tertentu lamanya. Modal sendiri menurut Riyanto (2010:240) terbagi menjadi tiga, yaitu :

1. Modal saham

2. Cadangan

3. Laba ditahan

ROE ialah rasio keuangan yang dapat menujukan besarnya laba bersih yang diperoleh dari ekuitas yang dimiliki perusahaan. Ini adalah keuntungan bersih yang diterima oleh pemegang saham dari investasi modal mereka di bank dan mempertaruhkan modalnya dengan harapan mendapatkan keuntungan yang layak. Semakin besar nilai rasionya, maka semakin imbal hasil yang diperoleh oleh para pemegang saham yang menyetorkan modalnya (Rosly dan Zaini: 2008). Rasio ini bertujuan untuk mengetahui serta mengukur seberapa besar tingkat pengembalian modal saham yang diinvestasikan keperusahaan melalui besarnya pendapatan atau laba yang dihasilkan perusahaan.

Mudharabah berasal dari kata dharb, berarti memukul atau berjalan. Pengertian memukul atau berjalan ini lebih tepatnya adalah seseorang memukulkan kakinya dalam menjalankan usaha. Menurut Antonio (2001: ) almudharabah adalah akad kerja sama antara dua pihak di mana pihak pertama (shahibul maal) menyediakan seluruh modal, sedangkan pihak lainnya menjadi pengelola. Keuntungan usaha secara mudharabah dibagi menurut kesepakatan yang dituangkan dalam kontrak, sedangkan apabila rugi ditanggung oleh pemilik modal selama kerugian itu bukan akibat si pengelola. Seandainya kerugian tersebut disebabkan oleh pengelola, maka si pengelola harus bertanggung jawab atas kerugian tersebut.

Berdasarkan undang-Undang Nomor 10 Tahun 1998 tentang Perubahan Atas Undang-Undang Nomor 7 Tahun 1992 tentang Perbankan, yang dimaksud deposito berjangka adlaah simpanan yang penarikannya hanya dapat dilakukan pada waktu-waktu tertentu menurut perjanjian antara penyimpan dengan bank yang bersangkutan. 
Kurniawan, et al/Jurnal Ekonomi Syariah Teori dan Terapan Vol. 4 No. 10 Oktober 2017: 847-859; ANALISIS PERBANDINGAN RETURN MODAL SENDIRI DAN EQUIVALENT RATE SIMPANAN MUDHARABAH PADA BANK UMUM SYARIAH DI INDONESIA PERIODE 2012-2015

Deposito pada perbankan syariah adalah deposito yang dijalankan berdasarkan prinsip syariah. Dalam hal ini, Dewan Syariah Nasional MUI telah mengeluarkan fatwa yang menyatakan bahwa deposito yang dibenarkan adalah deposito yang berdasarkan prinsip mudharabah.

$$
\text { Menurut Karim (2014:359-360), }
$$
tabungan mudharabah adalah tabungan yang dijalankan berdasarkan akad mudharabah. Dalam hal ini, bank syariah bertindak sebagai mudharib (pengelola dana), sedangkan nasabah bertindak sebagai shahibul maal (pemilik dana). Dari hasil pengelolaan dana mudharabah, bank syariah akan membagihasilkan dana sesuai dengan nisbah yang telah disepakati dan dituangkan dalam akad pembukaan rekening. Dalam mengelola dana tersebut, bank tidak bertanggung jawab apabila terjadi kerugian yang bukan disebabkan kelalaiannya. Namun apabila kerugian terjadi karena kesalahan bank, maka bank harus bertanggung jawab penuh.

Menurut Karim (2014:205-206), ada beberapa faktor yang harus ada dalam akad mudharabah adalah:

1. Pelaku (pemilik modal maupun pelaksana usaha). Dalam akad mudharabah harus ada minimal dua pelaku. Pihak pertama bertindak sebagai pemilik modal (shahibul maal), pihak kedua bertindak sebagai pelaksana usaha (mudharib).
2. Objek mudharabah. Pemilik modal menyerahkan modalnya sebagai objek mudharabah, sedangkan pelaksana usaha menyerahkan kerjanya sebagai objek mudharabah. Modal yang diserahkan bisa berbentuk vang atau barang yang dirinci berapa nilai vangnya. Sedangkan kerja yang bisa diserahkan bisa berbentuk keahlian, ketrampilan, selling skill, management skill, dan lain-lain.

3. Persetujuan. Kedua belah pihak harus secara rela bersepakat untuk mengikatkan diri dalam akad mudharabah.

4. Nisbah keuntungan. Nisbah ini mencerminkan imbalan yang berhak diterima oleh kedua belah pihak. Pembagian nisbah keuntungan ini biasanya disetujui kedua belah pihak di awal kesepakatan.

\section{METODE PENELITIAN}

\section{Pendekatan Penelitian}

Dalam penelitian ini, pendekatan yang di gunakan adalah kuantitatif komparatif. Penelitian ini meneliti tingkat return antar bank syariah di Indonesia periode 2012-2015 dengan menggunakan variabel ROE dan ROMD.

\section{Definisi Operasional Variabel}

1. Return On Equity 
Kurniawan, et al/Jurnal Ekonomi Syariah Teori dan Terapan Vol. 4 No. 10 Oktober 2017: 847-859; ANALISIS PERBANDINGAN RETURN MODAL SENDIRI DAN EQUIVALENT RATE SIMPANAN MUDHARABAH PADA BANK UMUM SYARIAH DI INDONESIA PERIODE 2012-2015

ROE ialah rasio kevangan yang dapat menujukan besarnya laba bersih yang diperoleh dari ekuitas yang dimiliki perusahaan. Ini adalah keuntungan bersih yang diterima oleh pemegang saham dari investasi modal mereka di bank dan mempertaruhkan modalnya dengan harapan mendapatkan keuntungan yang layak. Semakin besar nilai rasionya, maka semakin imbal hasil yang diperoleh oleh para pemegang saham yang menyetorkan modalnya (Rosly dan Zaini, 2008). Rumus dari rasio ini adalah:

$$
\text { ROE }=\frac{\text { Eaba ssbihm pajak }}{\text { Modal sendiri }} \times 100 \%
$$

2. Return deposito Mudharabah $(R O M D)=$ imbal hasil yang didapat nasabah setelah menginvestasikan dananya dalam akad mudharabah agar dikelola oleh bank syariah. Pembagian return didasarkan oleh nisbah pada kesepakatan awal (Diao dan Mbow, 2011).

\section{Jenis dan Sumber Data}

Penelitian ini menggunakan jenis data sekunder yang bersifat kuantitatif yaitu data yang didapatkan berasal dari laporan tahunan bank syariah yang dipublikasikan di website resmi masingmasing bank syariah.

\section{Populasi dan Sampel}

Populasi dalam penelitian ini adalah reksadana saham syariah yang terdapat di Indonesia. Pada penelitian ini, teknik pengambilan sampel yang digunakan adalah purposive sampling. Adapun kriteria pemilihan sampel penelitian ini adalah sebagai berikut:

a. Bank Umum Syariah yang telah berdiri sebelum tahun 2012 dan masih berdiri hingga 31 desember 2015.

b. Bank umum Syariah yang mempublikasikan laporan tahunannya pada tahun 20122015.

c. Sesuai dengan PBI no. 14/26/PBI/2012 Tentang Kegiatan Usaha dan Jaringan Kantor Berdasarkan Modal Inti Bank. Bank dikategorikan dalam kategori pengelompokan bank Sesuai Kelompok Usaha (BUKU). BUKU Bank Umum Konvensional yang masuk dalam range BUKU Bank Umum Syariah yaitu BUKU 1 sampai dengan BUKU 3. BUKU 1 adalah Bank dengan Modal Inti sampai dengan kurang dari Rp 1.000.000.000.000,00 (satu triliun rupiah); BUKU 2 adalah Bank dengan Modal Inti paling sedikit sebesar Rpl.000.000.000.000,00 (satu triliun rupiah) sampai dengan kurang dari Rp5.000.000.000.000,00 (lima triliun rupiah); BUKU 3 adalah Bank dengan Modal Inti paling sedikit sebesar Rp5.000.000.000.000,00 (lima triliun rupiah) sampai dengan kurang dari Rp30.000.000.000.000,00 (tiga triliun rupiah). 
Kurniawan, et al/Jurnal Ekonomi Syariah Teori dan Terapan Vol. 4 No. 10 Oktober 2017: 847-859; ANALISIS PERBANDINGAN RETURN MODAL SENDIRI DAN EQUIVALENT RATE SIMPANAN MUDHARABAH PADA BANK UMUM SYARIAH DI INDONESIA PERIODE 2012-2015

d. Telah beroperasi selama lebih dari atau sama dengan 4 tahun selama periode pengamatan 2012-2015.

\section{Prosedur Pengumpulan Data}

Prosedur pengumpulan data dalam penelitian ini dilakukan dengan teknik dokumentasi online dari laman publikasi resmi bank umum syariah terkait yang diteliti yang menyediakan data sekunder yang diperlukan dalam penelitian, agar kemudian dapat diteliti, dipelajari dan diolah sehingga dapat memberikan kesimpulan dari penelitian yang dilakukan.

\section{Teknik Analisis Data}

Penelitian ini menggunakan teknik uji One-way ANOVA (Analysis of Variance) untuk menguji ada atau tidaknya perbedaan antar bank syariah di Indonesia dengan menggunakan variabel ROE dan ROMD. Sebelum melakukan uji beda peneliti melakukan uji normalitas dan homogenitas sebagai syarat apakah data yang didapatkan terdistribusi normal atau tidak. Setelah melakukan uji OneWay ANOVA, peneliti melakukan uji PostHoc untuk mengetahui secara lebih detail bank syariah mana yang mengalami perbedaan secara signifikan. Uji Post-Hoc ini menampilkan perbandingan satu per satu antar bank syariah.

\section{HASIL DAN PEMBAHASAN}

Berdasarkan hasil uji analisis KruskalWallis untuk variabel ROE menujukkan hasil bahwa ada perbedaan yang signifikan diantara bank syariah di Indonesia periode 2012-2015. Lalu langkah selanjutnya ialah melakukan uji KruskalWallis dilakukan karena data variabel ROE tidak lulus uji homogenitas sehingga tidak bisa dilakukan uji One-Way ANOVA. Setelah dilakukan uji Kruskal-Wallis dilanjutkan uji Post-Hoc menggunakan Mann-Whitney test dengan hasil sebagai

\begin{tabular}{|l|l|r|}
\hline & & $\begin{array}{r}\text { Asymp. } \\
\text { Sig (2- } \\
\text { tailed) }\end{array}$ \\
\hline Muamalat & BNI Syariah & 0.021 \\
\hline & Panin Syariah & 0.021 \\
\hline BNI Syariah & BCA Syariah & 0.021 \\
\hline & BJB Syariah & 0.021 \\
\hline BCA Syariah & Panin Syariah & 0.021 \\
\hline
\end{tabular}

berikut:

\section{Uji Post Hoc Mann-Whitney}

Menurut uji Post-Hoc variabel ROE didapatkan hasil bahwa bank muamalat berbeda dengan bank BNI Syariah dan Panin Syariah, hal ini dikarenakan berdasarkan mean ROE BNI Syariah dan Panin Syariah mendapatkan mean tertinggi pertama dan kedua. Sedangkan bank muamalat mendapatkan mean terendah kedua. Salah satu penyebab bank Muamalat mendapatkan ROE rendah diakibatkan pada tahun 2014 nilai ROE yang didapat turun drastic dari tahun sebelumnya karena laba bersih yang 
Kurniawan, et al/Jurnal Ekonomi Syariah Teori dan Terapan Vol. 4 No. 10 Oktober 2017: 847-859; ANALISIS PERBANDINGAN RETURN MODAL SENDIRI DAN EQUIVALENT RATE SIMPANAN MUDHARABAH PADA BANK UMUM SYARIAH DI INDONESIA PERIODE 2012-2015

didapat pada tahun 2014 turun jauh dibandingkan tahun 2013.

Pada tahun 2013 laba bersih yang didapat sebesar Rp 475.846.659.000, sedangkan pada tahun 2014 hanya mendapatkan laba bersih sebesar $\mathrm{Rp}$ 58.916.694.000. Hal ini berbanding terbalik dengan jumlah ekuitas yang didapat bank muamalat pada tahun 2013 dan 2014 yang mengalami penignkatan. Hal inilah yang menyebabkan turunya ROE bank muamalat pada tahun 2014 meningkatnya jumlah ekuitas tidak disertai dengan meningkatnya laba bersih yang didapat. Menurut pendapat Hendiarto selaku Direktur Keuangan dan Operasional Bank Muamalat, mengatakan bahwa terjadinya kenaikan rasio pembiayaan bermasalah atau NPF dari $2.28 \%$ menjadi 3.3\% pada tahun 2014. Sementara marjin bunga bersih (NIM) sebagai indicator utama profitabilitas dari ekspansi pembiayaan mengalami penurunan dari 4.6\% pda tahun 2013 menjadi 3.82\% pada tahun 2014 (http://www.muamalatinstitute.com/kegiatan-berita/artikelsyariah).

Bank BNI Syariah mengalami perbedaan yang positif dengan bank BJB Syariah, BCA Syariah dan Panin Syariah. Hal ini disebabkan nilai ROE yang dihasilkan BNI Syariah selama periode 2012-2015 selalu mengalami peningkatan tiap tahunnya. Berbeda dengan bank BCA Syariah dan Panin Syariah yang mengalami fluktuasi nilai ROE selama periode 2012-2015 hal ini disebabkan karena peningkatan jumlah ekuitas yang disertai dengan penurunan laba bersih yang didapat hal inilah yang menyebabkan nilai ROE pada kedua bank mengalami fluktuasi. Berdasarkan laporan tahunan bank BJB Syariah tahun 2012 hal ini disebabkan pada tahun tersebut bank BJB Syariah mengalami kerugian sebesar 18.18 miliar rupiah hal ini disebabkan tingginya beban cadangan penghapusan pembiayaan sebesar 98.91 miliar rupiah. Lalu Bank BRI Syariah memiliki perbedaan dengan bank Panin Syariah. bank BRI Syariah mendapatkan penurunan ROE yang sangat drastic pada tahun 2014 yaitu sebesar $0.44 \%$ sedangkan pada tahun sebelumnya berhasil mencatat ROE sebesar $10.20 \%$.

Untuk variabel ROMD digunakan uji One-Way ANOVA karena hasil dari uji normalitas dan homogenitas yang dilakukan untuk variabel ROMD signifikan sehingga dapat dilakukan uji ANOVA. Hasil uji ANOVA untuk variabel ROMD didapatkan hasil yaitu $0.235>0.05$, tidak signifikan sehingga dapat ditarik kesimpulan bahwa tidak terdapat perbedaan diantara keenam bank umum syariah yang menjadi sampel penelitian. Tetapi apabila dilihat dari rata-rata ROMD yang didapat bank syariah tetap terdapat perbedaan hanya saja perbedaannya tidak signifikan.

\section{Rata-rata ROMD Bank Syariah di Indonesia}


Kurniawan, et al/Jurnal Ekonomi Syariah Teori dan Terapan Vol. 4 No. 10 Oktober 2017: 847-859; ANALISIS PERBANDINGAN RETURN MODAL SENDIRI DAN EQUIVALENT RATE SIMPANAN MUDHARABAH PADA BANK UMUM SYARIAH DI INDONESIA PERIODE 2012-2015

\begin{tabular}{|l|l|}
\hline Bank Syariah & ROMD \\
\hline Muamalat & 5.72 \\
\hline BNI Syariah & 4.71 \\
\hline BRI Syariah & 6.65 \\
\hline BCA Syariah & 5.79 \\
\hline BJB Syariah & 6.85 \\
\hline Panin Syariah & 5.96 \\
\hline \multicolumn{2}{|c|}{ Pada hasil Uji ANOVA yang } \\
\hline
\end{tabular}

dilakukan untuk mencari perbedaan ROMD yang signifikan antar bank syariah di Indonesia periode 2012-2015, ternyata tidak ada perbedaan yang signifikan antar bank syariah di Indonesia. Hanya beberapa bank yang memiliki perbedaan yang signifikan yaitu antara BNI Syariah dengan BRI Syariah dan BJB Syariah. Tidak adanya perbedaan ROMD yang signifikan kemungkinan dikarenakan hasil ROMD antar bank syariah tiap tahun tidak terpaut jauh satu sama lainnya. Setiap tahun dari 2012-2015 ROMD tiap bank syariah yang menjadi sampel penelitian hasil ROMDnya tidak terlalu terpaut jauh dari bank syariah yang satu dengan bank syariah yang lainnya. Ini menandakan bahwa terjadi persaingan yang cukup ketat pada bank syariah dalam hal menarik dana investasi dari masyarakat.

Bank syariah yang mendapatkan rata-rata ROMD tertinggi ialah BJB Syariah dengan nilai $6.85 \%$ berarti bank BJB Syariah mampu memaksmalkan hasil dana yang dikumpulkan lewat kontrak mudharabah dengan baik, dengan cara menyalurkan kembali dana yang berhasil dihimpun tersebut. Sedangkan rata-rata ROMD terendah didapat oleh BNI Syariah dengan prosentase sebesar $4.71 \%$. Tetapi bukan berarti bahwa BNI Syariah gagal dalam menyalurkan kembali dana yang berhasil dihimpunnya hanya saja pihak BNI Syariah kurang maksimal dalam melakukan pembiayaan. Karena apabila dilihat dalam laporan tahunannya, bank BNI Syariah berhasil mengumpulkan total dana mudharabah cukup tinggi. Bahkan apabila dibandingkan dengan total dana mudharabah yang dihimpun oleh BJB Syariah, dana milik BNI Syariah lebih tinggi dibandingkan BJB Syariah. hal ini membuktikan bahwa, ada ketidakmaksimalan pihak manajemen BNI Syariah dalam mengelola dana mudharabahnya. Sehingga nilai ROMD yang muncul untuk BNI Syariah nilai kecil dibandingkan dengan bank syariah lainnya. Tetapi nilai ROMD yang didapat BNI Syariah bukan berarti jelek karena tidak ada takaran pasti berapa prosentase ROMD yang bagus.

Menginvestasikan dana pada bank syariah dengan akad mudharabah sangat baik, hal ini bisa dilihat dari laporan tahunan bank BJB Syariah tahun 2012 dimana bank BJB Syariah mengalami kerugian sebesar 18.18miliar rupiah dan mengakibatkan kinerja kevangannya menurun akan tetapi hal tersebut tidak berpengaruh pada imbal hasil yang diberikan untuk para nasabah akad mudharabah tetap ada. Jadi bagi nasabah yang ingin berinvestasi dengan selalu mengharapkan mendapatkan imbal hasil kontak mudharabah pada 
Kurniawan, et al/Jurnal Ekonomi Syariah Teori dan Terapan Vol. 4 No. 10 Oktober 2017: 847-859; ANALISIS PERBANDINGAN RETURN MODAL SENDIRI DAN EQUIVALENT RATE SIMPANAN MUDHARABAH PADA BANK UMUM SYARIAH DI INDONESIA PERIODE 2012-2015

bank syariah sangat cocok. Menginvestasikan dana pada bank syariah dengan akad mudharabah sangat aman, karena bank syariah menjamin tetap mengembalikan dana yang diinvestasikan apabila terjadi kerugian. Hal ini dilakukan bank syariah untuk mencegah terjadinya fund flight yaitu berpindahnya dana pada bank syariah ke bank konvensional. Menurut Gianisha Oktaria Putri dalam penelitiannya yang berjudul "Analisis Bagi Hasil Deposito Mudharabah pada Bank Syariah di Indonesia" mengatakan bahwa sistem yang digunakan perbankan syariah di Indonesia adalah revenue sharing dimana pola bagi hasil ini menguntungkan nasabah dibandingkan dengan bank syariah. Pola bagi hasil revenue sharing menekankan bank syariah sebagai mudharib membayarkan bagi hasil kepada deposan tanpa menguranginya dengan biaya-biaya tertentu. Dana yang diinvestasikan oleh deposan juga aman apabila bank syariah mengalami kerugian, karena dananya dijamin oleh Lembaga Penjamin Simpanan. Hal inilah, yang menyebabkan tidak terdapatnya perbedaan yang signifikan pada akad mudharabah antar bank syariah di Indonesia.

Hasil analisis ROE dan ROMD pada bank syariah di Indonesia dapat digunakan sebagai salah satu pertimbangan investasi oleh investor ataupun nasabah yang ingin menanamkan dananya pada bank syariah. faktor return atau tingkat bagi hasil merupakan suatu hal yang biasanya pertama dilihat oleh para calon investor ataupun nasabah yang ingin menginvestasikan dananya. Dari hasil return inilah kita bisa lihat kinerja bank syariah dalam mengelola dana yang dimilikinya. Apabila tren return yang didapat tiap tahun meningkat, mengindikasikan bahwa kinerja bank syariah tersebut dalam mengelola dananya sangat baik. Dan bisa menjadi pertimbangan para investor atau nasabah bila ingin berinvestasi.

\section{SIMPULAN}

Berdasarkan hasil analisis dan pembahasan yang telah dilakukan, maka dapat diambil kesimpulan sebagai berikut:

1. Hasil pengujian uji Kruskal-Wallis pada ROE didapatkan kesimpulan bahwa ada perbedaan return on equity antara bank umum syariah di Indonesia periode 2012-2015. Dapat diketahui bahwa bank BNI Syariah memiliki rata-rata return on equity yang paling tinggi, sedangkan bank BJB Syariah memiliki rata-rata return on equity terendah. Secara lebih detail, hasil uji Post Hoc Mann-Whitney menyimpulkan bahwa perbedaan ROE antar bank umum syariah di Indonesia pada tahun 2012-2015 terdapat diantara Bank BNI Syariah 
Kurniawan, et al/Jurnal Ekonomi Syariah Teori dan Terapan Vol. 4 No. 10 Oktober 2017: 847-859; ANALISIS PERBANDINGAN RETURN MODAL SENDIRI DAN EQUIVALENT RATE SIMPANAN MUDHARABAH PADA BANK UMUM SYARIAH DI INDONESIA PERIODE 2012-2015

dengan Bank Muamalat, Bank BJB Syariah, Bank BCA Syariah, dan Panin Syariah. Kemudian diantara Bank BJB Syariah dengan Bank BRI Syariah dan Panin Syariah. Alasan yang menyebabkan terjadinya perbedaan ROE bank syariah ialah meningkatnya jumlah pembiayaan bermasalah dan juga menigkatnya jumlah ekuitas tetapi laba bersih yang didapatkan mengalami penurunan.

2. Untuk hasil pengujian uji $F$ (ANOVA) pada ROMD didapatkan kesimpulan bahwa tidak ada perbedaan return on mudharabah deposits antara bank umum syariah di Indonesia periode 20122015. Tetapi apabila dilihat dari mean ROMD bank syariah terdapat perbedaan hanya saja tidak signifikan. Hal ini membuktikan bahwa terjadi persaingan yang ketat antar bank syariah dalam hal memberikan return untuk nasabah yang menginvestasikan dananya pad akad mudharabah. Penerapan sistem PER dimana bank syariah memberikan labanya pada nasabah agar imbal hasil yang diberikan sama dengan bunga bank konvensional.

Saran

Penelitian ini tidak terlepas dari keterbatasan yang meliputi perbandingan antar satu variabel saja, dua variabel yang digunakan dalam penelitian ini adalah ROE dan ROMD. Dan juga hanya meneliti selama empat periode terakhir. Saran yang dapat disampaikan dari simpulan diatas yaitu:

1. Bagi Perbankan Syariah

Untuk meningkatkan ROE perbankan syariah diperlukan kebijakan yang bersifat internal dalam perusahaan, perlunya para dewan direksi untuk membahas lebih lanjut dalam RUPS. Pengendalian dan perbaikan dapat dilakukan dengan meminimalisasi kredit macet pada bank syariah. Jadi bank syariah harus lebih cermat dan teliti dalam memberikan pembiayaan terutama pembiayaan yang membutuhkan modal yang besar. Sedangkan untuk meningkatkan ROMD pada bank syariah bisa dilakukan dengan cara meningkatkan pelayanan kepada nasabah dalam mengatasi persaingan dengan ban syariah lainnya. Lalu bisa dilakukan dengan meningkatkan prinsip kehati-hatian dalam menyalurkan pembiayaan kepada nasabah. Selanjutnya memberikan bagi hasil yang baik dalam meningkatkan dana pihak ketiga.

2. Bagi Investor atau Nasabah Investor dan nasabah/deposan diharapkandapatmempertimbang kan hasil nilai ROE dan ROMD 
Kurniawan, et al/Jurnal Ekonomi Syariah Teori dan Terapan Vol. 4 No. 10 Oktober 2017: 847-859; ANALISIS PERBANDINGAN RETURN MODAL SENDIRI DAN EQUIVALENT RATE SIMPANAN MUDHARABAH PADA BANK UMUM SYARIAH DI INDONESIA PERIODE 2012-2015

sebagai salah satu pertimbangan sebelum memilih dan melakukan investasi pada bank syariah tersebut. Bagi investor yang ingin menginvestasikan dananya dalam bentuk saham atau membeli sebagian dari kepemilikan bank syariah disarankan untuk berinvestasi pada bank BNI Syariah karena setelah diuji BNI Syariah memiliki nilai ROE paling tinggi. Sedangkan bagi nasabah atau deposan yang ingin menginvestasikan dananya pada akad mudharabah bank syariah disarankan untuk berinvestasi pada bank BJB Syariah. Sebenarnya tidak ada takaran yang pasti tentang nilai ROE dan ROMD yang baik, hanya saja kita dapat melihatnya dari tren ROE dan ROMD beberapa tahun belakangan. Apabila nilai atau tren yang dihasilkan positif dan selalu mengalami kenaikan bisa dikatakan bank tersebut baik dalam hal ROE ataupun ROMD.

3. Bagi peneliti selanjutnya

Bagi peneliti selanjutnya diharapkan menambahkan variabel lain, untuk menghitung return yang diberikan pada pihak ketiga maupun pada peilik modal sendiri. Selain itu, diharapkan juga untuk membandingkan ROE dan ROMD dengan bank syariah di
Negara lain seperti Malaysia, Bruni Darussalam, dan lainnya.

\section{DAFTAR PUSTAKA}

Amaroh, Siti. (2012). Perbandingan Imbal Hasil Kontrak Mudharabah dan Partisipasi Modal Dalam Penghimpunan Dana Bank Syariah. Inferensi, Jurnal Penelitian Sosial Keagamaan Vol 7, No. 1, Juni 2013.

Antonio, Muhammad Syafi'i. 2001. Bank Syariah Dari Teori ke Praktik. Jakarta: Gema Insani.

Arifin, Zainul. 2003. Dasar-dasar Manajemen Bank Syariah. Jakarta: Pustaka Alfabet.

Diaw, Abdou \& Abdoulaye Mbow. 2011. "A Comparative Study of The Returns on Mudharabah Deposit And On Equity in Islamic Banks". Emerald Insight, Vol. 27, No.4

Fahmi, Irham. 2006. Analisis Investasi dalam Perspektif Ekonomi dan Politik. Bandung: PT Refika Aditama.

Gianisha, Oktaria Putri. 2012. Analisis Bagi Hasil Deposito Mudharabah pada Bank Umum Syariah di Indonesia. Tidak diterbitkan. Depok Fakultas IImu Sosial dan IImu Politik Universitas Indonesia.

Halim, Abdul.2005. Analisis Investasi. Jakarta: Salemba Empat.

Huda, Nurul dan Mustafa Edwin Nasution, 2007. Investasi Pada Pasar Modal Syariah. Jakarta. Prenada Media Group.

Karim, Adiwarman. 2005. Islamic Banking Figh and Financial Analysis. Jakarta: PT. Raja Grafindo Persada

Kasmir. 2010. Manajemen Perbankan. Jakarta: Rajawali Pers.

2010. Dasar-dasar Perbankan. Jakarta: Rajawali Pers.

Nafik H.R, Muhammad. 2009. Bursa Efek dan Investasi Syariah. Jakarta: PT Serambi llmu Semesta 
Kurniawan, et al/Jurnal Ekonomi Syariah Teori dan Terapan Vol. 4 No. 10 Oktober 2017: 847-859; ANALISIS PERBANDINGAN RETURN MODAL SENDIRI DAN EQUIVALENT RATE SIMPANAN MUDHARABAH PADA BANK UMUM SYARIAH DI INDONESIA PERIODE 2012-2015

Nazir, Habib dan Muhammad Hasanuddin. 2004. Ensiklopedi Ekonomi dan Perbankan Syariah. Bandung: Kaki Langit.

Rosly, S.A. and Zaini, M.A.M. (2008). Riskreturn analysis of Islamic banks' investment deposits and shareholders' fund", Managerial Finance, Vol. 34 No. 10.

Suryomurti, Wiku. 2011. Super Cerda Investasi Syariah. Jakarta: Qultum Media.

Tandelilin, Eduardus. 2001. Analisis investasi dan Manajemen Portofolio. Yogyakarta: BPFE.

http://www.muamalatinstitute.com/kegiatan-berita/artikelsyariah, diakses 25 Januari 2017

http://keuangan.kontan.co.id/news/3faktor-penyebab-laba-bri-syariahmerosot-97, diakses 25 Januari 2017 